\title{
Prevalence, Pattern and Correlates of Study Difficulty Among Students of College of Health Sciences Ladoke Akintola University of Technology Osogbo
}

\author{
J. Falade \\ Department of Mental Health \\ Afe Babalola University Ado Ekiti, Ekiti State, Nigeria \\ A. Akinsulore \\ Department of Mental Health \\ Obafemi Awolowo University Ile Ife, Osun state, Nigeria \\ B. A. Eegunranti \\ Department of Psychiatry \\ LAUTECH Teaching Hospital, Osogbo - Osun State, Nigeria \\ J. E. Tobih \\ Department of Otorhinolaryngology Head and Neck Surgery \\ LAUTECH Teaching Hospital, Osogbo - Osun State, Nigeria
}

A. C. Ogundiran

Department of Guidance and Counselling

University of Ibadan, Nigeria

\begin{abstract}
0. Ibigbami
Department of Mental Health, Obafemi Awolowo University Ile Ife Osun state, Nigeria
\end{abstract}

\section{Ogundiran (Corresponding Author)}

Department of Otorhinolaryngology Head and Neck Surgery LAUTECH Teaching Hospital, Osogbo - Osun State, Nigeria

\begin{abstract}
Introduction - Study difficulty is the inability to obtain maximum result from efforts put into studying. It can negatively affect the physical and mental stability of the student leading to increased dropout from school. Objective - This study examined the prevalence, pattern and correlates of study difficulty among students of College of Health Sciences, Ladoke Akintola University of Technology Osogbo. Methods - Two hundred and seventy-seven students of the College were consecutively recruited. Each student filled socio-demographic questionnaire, University College London Study Questionnaire (UCLSQ), Brief COPE Questionnaire and General Health Questionnaire. The Statistical Package for Social Science (SPSS) software (version 21) was used for the analysis. Results -The mean age of the respondents was 26.3 years. The proportion of Medical, Nursing and Medical Laboratory Science students were $42.6 \%, 31.8 \%$ and 25.6\% respectively. Most of the respondents were from married home $\mathbf{7 7 . 5 \% ) ,}$ monogamous setting $(\mathbf{7 8 . 0 \%})$, parents with tertiary education and higher class of occupation. The prevalence of study difficulty among the respondents was $\mathbf{5 2 . 0 \%}$.
\end{abstract}


Multiple linear regression analysis with stepwise method showed that respondents using less of adaptive coping strategies $(p=0,005)$ and presence of psychiatric morbidity $(p<0.001)$ were independently associated with the presence of study difficulty. Conclusion - This study has shown that psychiatric morbidity and maladaptive coping strategy use were more common among students with study difficulty. A routine mental health assessment and practical teaching of adaptive coping strategy in the citadels of learning in particular the tertiary level/medical and paramedical professions.

\section{INTRODUCTION}

Studying is central in the life of a student because passing examination depends on how effectively the student studies. Difficulty in studying is one of the most commonly encountered symptoms amongst undergraduates because students are exposed to a specific set of occupational and environmental hazards in conjunction with the primary responsibility of studying which may impact negatively on ability to study effectively $[1,2]$. Study difficulty is impairment in the capacity to study effectively or obtain maximal effect from studying. It may be because of diminished impetus, impaired ability to concentrate or to retain and recall presented materials [3]. Study difficulty form part of the principal complaint among students, its quantification is difficult because the symptoms vary in degree and form, and change over time $[2,3,4]$. In a cohort study across a four year period, Lucas found that of the15 percent of the cohort who received brief psychotherapy, more than three-quarters had study difficulty, of the 26 per cent of the cohort who never attended the Student Health Centre nearly half replied yes to a question asking whether they had experienced recurring work difficulty [3].

In Canada at the Psychiatric Division of Queen's University Students Health Centre, 47\% of students complained of study difficulty [2]. Blain and McArthur reported study difficulty in $50 \%$ of the students attending student health services at Harvard [5]. In Nigeria, a study among undergraduate students in Abuja revealed a prevalence of 53.8\% [6] while Osasona et al 2011 found $4.5-15.5 \%$ of undergraduates in Benin to have study difficulty [7].

\section{Theoretical analysis of study difficulty}

According to Crown, three major factors are associated with study difficulty. The factors are psychological, socio-cultural and inter-reactional [4].

\section{Psychological Factors}

Psychological factors impairing studying are intellectual, emotional, or motivational. Intellectual factors affect thinking, reasoning, memorizing and problem solving [4]. Emotional factors relate both to personality pattern (such as introversion- extraversion) and to psychiatric symptom patterns. Motivational factors may include conflict with basic drives (such as sexuality or aggression) and with acquired drives (such as interests and the level of aspiration).

\section{Socio- Cultural Factors}

Environment and cultural practices are relevant to learning. The direct environment is sustained in a cultural milieu, which may manipulate, help, or perhaps handicap studying, for example, students moving from one type of home sub-culture to a different one at college. The student's socio-cultural environment is essentially formed by the features of the institution. Attitudes and expectation of students differ. Institutional factors such as how impressive, academically, vocationally and research orientated the institution is, cordial staff-students relationships or the contrary greatly affect students' attitude. Socio-cultural factors include economic factors, relationships with the authorities and friends, and educational pressure [3, 4]. 
Falade, J., Eegunranti, B. A., Tobih, J. E., Ogundiran, A. C., Ibigbami, O., Akinsulore, A., Ogundiran, O. (2019). Prevalence, Pattern And Correlates Of Study Difficulty Among Students Of College Of Health Sciences Ladoke Akintola University Of Technology Osogbo. Advances in Social Sciences Research Journal, 6(9) 322-338.

\section{Inter-ractional Factors}

The paradox of studying is that student may be less effective in one environment than another. Besides, there can also be constant changes in his/ her study effectiveness from the first year upward. This may result from the complex interplay between psychological, social-cultural and institutional factors $[3,4]$.

\section{Measurement of Study Difficulty}

To measure study difficulty objectively, the University College London Study Difficulty Questionnaire (UCLSQ) was designed by Crown based on the types of complaints made by students [4]. Principal components analyses on different occasion showed that study difficulty could be related to three independent factors:

- Psychoneurotic difficulties alone (measured by the anxiety, depression, obsessionalty and somatization subscales).

- Motivational difficulty alone (as measured by disorganized -distractible and low motivation subscales).

- A mixture of both the neurotic and motivational difficulties as measured by the work satisfaction, syllabus -boundness or sylbism and obsessionality scales.

\section{CLASSIFICATION OF STUDY DIFFICULTY}

There have been several improvements on the classification of study difficulty. The first attempt was by Malleson. He initially recognized three types of common presentations among students. These were anxiety, apathetic withdrawal and somatic symptoms over study [8]. He latter recognized primary and secondary study difficulties. Primary consist of obsessional, disorganized, retention and recall difficulties in which work is learnt but not presented. The secondary type was generally attributed to personal problems. Ryle classified students presenting with study difficulty into disorganized and dynamic categories on the other hand [2, 9], classified study difficulty into primary and secondary types. In the primary type, study is disrupted because of poor budgeting of available time. He subdivided secondary study difficulty into those associated with uncommonly encountered conditions (such as dyslexia, schizophrenia and amotivational syndrome) and those associated with commonly encountered conditions. Conditions commonly encountered are adjustment reactions, developmental problems, anxiety states, depression and psychoneurotic problems.

Crown et al after an extensive review of literature on the study difficulty grouped the associated factors into three and attempted to objectively measure study difficulty among students [2]. He identified psychological, socio-cultural and interactional factors. The recent classification is the one proposed by Morakinyo, which also divided study difficulty into primary and secondary types [10]. He associated the secondary type with psychiatric problems such as personality disorders, substance abuse, neurotic related, and psychotic related disorders, while primary type is not associated with psychiatric disorders and is divisible into 5 sub-types. These include the motivational, educational, psycho-physiological, socio-cultural and organic-medical sub-types.

Morakinyo's classification is in contrast with those of Malleson and Ryle, but represented a marked improvement on the one proposed by Handforth. It is comprehensive and encompassing a wide variety of factors, which may be associated with study difficulty, it appears more applicable across cultures, and it identifies the possible underlying mechanisms involved in the genesis of study difficulty by these factors. 
Table 1 morakinyo's classification of study difficulty

\begin{tabular}{|c|c|c|c|c|}
\hline & TYPE & $\begin{array}{c}\text { SUB } \\
\text { TYPES }\end{array}$ & & POSSIBLE UNDERLYING FACTORS \\
\hline A. & PRIMARY & & & \\
\hline \multirow[t]{5}{*}{$\begin{array}{l}\text { Not associated } \\
\text { with } \\
\text { psychiatric } \\
\text { illness }\end{array}$} & & 1 & Educational/ Psychological & $\begin{array}{l}\text { (a)Deficient intellectual capacity. } \\
\text { (b)Impaired reading comprehension } \\
\text { ability. } \\
\text { (c)Retention-recall difficulties. } \\
\text { (d)Aptitude-Vocational in- } \\
\text { congruencies. } \\
\text { (e)Poor study habit (e.g. time } \\
\text { budgeting, etc.). }\end{array}$ \\
\hline & & 2. & Behavioral/ Motivational & $\begin{array}{l}\text { (a)Disorganisation. } \\
\text { (b)Syllabus-bound/Syllabus-Free } \\
\text { work manner. } \\
\text { (c)Low motivation. } \\
\text { (d)Poor concentration/ Distractibility. }\end{array}$ \\
\hline & & 3 & Social Cultural & $\begin{array}{l}\text { (a)Learning in second language and } \\
\text { understanding alien constructs } \\
\text { (Reading-Comprehension difficulties). } \\
\text { (b)Attitude to education. } \\
\text { (c)Loneliness, social deprivation. } \\
\text { (d)Adjustment and interpersonal } \\
\text { difficulties. } \\
\text { (e)Structural and dynamic } \\
\text { characteristics of the education } \\
\text { system and institution. } \\
\text { (f)Community expectations and } \\
\text { indebtedness. } \\
\text { (g)Family events. }\end{array}$ \\
\hline & & 4. & Psycho physiological & $\begin{array}{l}\text { (a)Sensory deprivation (e.g. poor } \\
\text { lighting in reading room, classroom, or } \\
\text { at home). } \\
\text { (b)Exertion-exhaustion stress. } \\
\text { (c)Sleep deprivation. }\end{array}$ \\
\hline & & 5 & Organic-Medical & $\begin{array}{l}\text { (a)Perceptual disabilities (e.g. poor } \\
\text { sight, hearing). } \\
\text { (b)Head injury and other dementing } \\
\text { brain diseases. } \\
\text { (c)Arrest or retardation of } \\
\text { development and growth. }\end{array}$ \\
\hline B. & SECONDARY & & & \\
\hline \multirow{3}{*}{$\begin{array}{l}\text { Associated with } \\
\text { psychiatric } \\
\text { disorder. }\end{array}$} & & 1. & $\begin{array}{l}\text { Personality-Related } \\
\text { (a) Hysterical Personality }\end{array}$ & $\begin{array}{l}\text { (i)Easy extinction of conditioning/ } \\
\text { learning. }\end{array}$ \\
\hline & & 2. & $\begin{array}{l}\text { Substance (Drug) Abuse or } \\
\text { Dependence-related }\end{array}$ & $\begin{array}{l}\text { (i)Drug induced a motivational } \\
\text { syndrome. } \\
\text { (ii)Concentration and comprehension } \\
\text { impairment under drug influence }\end{array}$ \\
\hline & & 3 & $\begin{array}{l}\text { Neurotic-related } \\
\text { (a) Somatic anxiety } \\
\text { (b) Anticipatory or Reactive } \\
\text { phobic-anxiety related to } \\
\text { fear of failure and or } \\
\text { repeated failure. } \\
\text { (c) Neurasthenia. } \\
\text { (d) Adjustment Disorder. } \\
\text { (e) Other Neuroses in which } \\
\text { study has special symbolic } \\
\text { significance, e.g. (Brain Fag }\end{array}$ & $\begin{array}{l}\text { (i)Impairment of } \\
\text { learning/performance due to hyper } \\
\text { arousal. } \\
\text { (ii)Interest disorder, } \\
\text { (iii)Social-cultural factors, } \\
\text { (iv)Psychophysiological factors, } \\
\text { (v)Social-cultural factors as above. } \\
\text { (vi)Constitutional factors. }\end{array}$ \\
\hline
\end{tabular}


Falade, J., Eegunranti, B. A., Tobih, J. E., Ogundiran, A. C., Ibigbami, O., Akinsulore, A., Ogundiran, O. (2019). Prevalence, Pattern And Correlates Of Study Difficulty Among Students Of College Of Health Sciences Ladoke Akintola University Of Technology Osogbo. Advances in Social Sciences Research Journal, 6(9) 322-338.

\begin{tabular}{|l|l|l|l|l|}
\hline & & syndrome). & \\
\hline & & 4. & $\begin{array}{l}\text { Psychotic-related (a) } \\
\text { Schizophrenia }\end{array}$ & $\begin{array}{l}\text { (i)Aboulia. } \\
\text { (ii)Interest disorder. } \\
\text { (iii)Constitutional factors. }\end{array}$ \\
\hline
\end{tabular}

\section{Study Setting and Participants}

\section{METHODOLOGY}

The study employed a cross sectional descriptive design. The sample was recruited among undergraduates from the Departments of Medicine, Nursing and Medical Laboratory Science of College of Health sciences, Ladoke Akintola University of Technology, Osogbo. These are the departments of the College of Health Sciences, at Osogbo. They are the departments in need of clinical and laboratory rotations provided by the Teaching Hospital which is located at Osogbo.

\section{Study Design}

Stratified random sampling method was used in the study. The population was divided according to their departments, each department was divided according to their levels and each level was further divided by gender. At the final stage, the sample was selected using simple random method. The College of Health Sciences Oshogbo as at 2015/16 academic session had 734 students. Departments of Medicine, Nursing and Medical Laboratory Science had 313, 234 and 187 students respectively

The sample size (277) was sub-allocated to each department (Medicine, Nursing and Medical Laboratory Science).The sample size for each department was calculated by multiplying the total number of students in each department by the calculated sample size (277) and dividing the result by the total number of students in the College of Health Sciences, LAUTECH, Osogbo (734). Thus, the sample was distributed as follows; Medicine, 118; Nursing, 88 and Medical Laboratory Sciences, 71 respondents.

In addition, proportionate distribution by gender was ensured at all levels by multiplying the number belonging to each gender in the level by the calculated sample size for the level and dividing by the total number of students in the level. The final participant at each level was selected by balloting. Samples were collected between April and August 2017.

\section{Ethical Consideration}

Ethical approval was obtained from the Research Ethics Committee of the LAUTECH Teaching Hospital, Osogbo. Written permission was obtained from the Provost, College of Health Sciences, LAUTECH, Osogbo. Participation was voluntary, and informed consent was obtained from the students with the understanding that the information provided will be confidential and the study would be non -malevolence.

\section{Instruments}

\section{Socio-Demographic Schedule/Profoma}

This section contained the information on the socio-demographic profiles of respondents. It contained the following items age, sex, religion, marital status, department, self-rate academic performance. The schedule also includes source of finance, number of children the parent had, position in the family, and marital status of the parent, family type and parents' occupation.

\section{The General Health Questionnaire (GHQ)}

David Goldberg designed the GHQ. It is a self-administered screening instrument anticipated at detecting non-psychotic psychiatric disorders. The questionnaire focuses on two major areas that are incapability to carry out normal function and the appearance of new and distressing 
phenomena. It is designed for normal population, clinic attendants, adolescent and adults. GHQ-12 had been validated in Nigerian language [11].

\section{The University College London Study Questionnaire}

The University College London Study Questionnaire (UCLSQ) was designed by Crown and his colleagues to assess study difficulty in students. The questionnaire is a product of careful evaluation of clinically observed complaints of students with study difficulty by the authors and other researchers, physicians and psychotherapists involved in student health work. They tapped only affective and motivational factors contributing to study difficulty, excluding sociocultural and inter-ractional factors [2].

The UCLSQ has been used to evaluate study difficulty in many centers in Nigeria ${ }^{1,7}$. In its original form, it consists of seven scales. Each scale consists of nine items with three possible responses. An alteration of the instrument by Lucas in 1976 [12] added another scale bringing the total number of scales to 8. The three (3) possible responses of mainly true, neither true or false and mainly false are assigned scores of two (2), one and zero respectively. There are nine (9) questions for each subscale. The total scores obtainable for each range from $0-18$. The following are the subscales of UCLSQ: Anxiety (ANX), Obsessionality (OBS); Depression (DEP); Disorganized- distractible (DIS); Low-motivation (LMOT); Somatic (SOM); Work satisfaction (WSAT) and Syllbism (SYL).With the addition of the eighth scale, the items are arranged so that Anxiety items are items 1, 9, 17, 25 etc., Obsessionality items are numbers 2,10,18,26, etc., with the other subscales following similar sequence on the instrument.

On the scale, respondent was divided into three categories namely low scorers, moderate scorers, and high scorers ${ }^{3}$. Hence, respondents with scores 1 SD below the mean will be termed low scorers. High scorers will be respondents with scores higher than 1SD above the mean. Moderate scorer will be those with scores between low and high scorers.

High scorers on the subscales will be considered to have study difficulty except on work satisfaction in which low scorers are considered to be having study difficulty

Using a cut-off point of 3 for GHQ 12, students who scored $\geq 3$ was regarded as having possible psychiatric morbidity (i.e., 'GHQ 12 cases')150, 151and those who scored <3, were regarded as having no morbidity (i.e., 'GHQ 12 'non-cases'). During submission, the mobile phone number of the 'cases' and a proportion (10\%) of the 'noncases' who are selected by simple random method was collected and they were interviewed privately (at the second stage) in the office at different times for psychiatric diagnoses using the MINI by the researcher.

\section{DATA ANALYSIS}

The Statistical Package for Social Sciences (SPSS version 21) was used for Data analysis. The socio-demographic details of respondents were reported using descriptive statistics such as frequency, means, and standard deviation (SD). Chi-square test, Student t- test, and correlations were used to determine the relationship between study difficulty and sociodemographic details, coping strategies and psychiatric morbidity. Multivariate statistical techniques such as binary logistic regression were employed to identify the factors that were significantly associated with study difficulty among the study participants. Confidence interval was set at $95 \%$ and all tests were two-tailed. Statistical significance was considered at a p value less than 0.05 .

\section{RESULTS \\ Socio-Demographic Characteristics of the Respondents}

Two hundred and seventy-seven questionnaires were distributed, completed and returned, giving a response rate of $100 \%$. Table 2 shows the socio-demographic characteristics of 
Falade, J., Eegunranti, B. A., Tobih, J. E., Ogundiran, A. C., Ibigbami, O., Akinsulore, A., Ogundiran, O. (2019). Prevalence, Pattern And Correlates Of Study Difficulty Among Students Of College Of Health Sciences Ladoke Akintola University Of Technology Osogbo. Advances in Social Sciences Research Journal, 6(9) 322-338.

respondents. Most (73.3\%) of the respondents were 25 years and above, single (88.1\%), Christians (79.4\%) and from Yoruba ethnic group (91.3\%), Female respondents were 58.1\% of the sample.

Monthly allowance of the respondents ranged from \#3,000 to \#70,000. One hundred and thirty two (47.7\%) reportedly had monthly allowance of less than \#20,000;46.2\%, between \#20,000 and $\# 40,000$ while $6.1 \%$ had monthly allowance more than \#40,000. Majority $(77.6 \%)$ of the respondents were not satisfied with their monthly allowance. The main sources of finance were the parents $(78.0 \%)$ while $11.6 \%$ were self-sponsored. The academic characteristics of the respondents were presented in Table 3. About half of the respondents $(50.9 \%)$ subjectively rated themselves above average academically, while a few were below average. Majority of the respondents were in the second-class upper division. Most respondents (77.8\%) had parents that were married and from monogamous setting (78.0\%). Majority (78\% of fathers and 75.8\% of mothers) had tertiary education. Two hundred and six $(74.4 \%)$ of fathers and one hundred and seventy-nine (64.6\%) mothers of the respondents had employment in the high-class category. Eighty-seven (31.4\%) and one hundred (36.1\%) were the first child of their fathers and mothers respectively while others were last children and the children between the first and last child (Table 4).

Table 2: Socio-Demographic Characteristics of the Respondents

\begin{tabular}{|l|c|c|}
\hline Variable & Frequency & Percentage \\
\hline Age & 74 & \\
$<25$ & 203 & 73.7 \\
$\geq 25$ & & \\
\hline Sex & 116 & 41.9 \\
Male & 161 & 58.1 \\
Female & & \\
\hline Religion & 220 & 79.4 \\
Christianity & 55 & 19.9 \\
Islam & 2 & 0.7 \\
Traditional & & \\
\hline Marital status & 244 & 88.1 \\
Single & 33 & 11.9 \\
Married & & \\
\hline Ethnicity & 253 & 91.3 \\
Yoruba & 17 & 6.2 \\
Ibo & 7 & 2.5 \\
Hausa & & \\
\hline Monthly allowance & 132 & 47.7 \\
$<20.000$ & 128 & 46.2 \\
20,000-39,999 & 17 & 6.1 \\
$\geq 40.000$ & & \\
\hline Satisfaction with monthly allowance & 215 & 77.6 \\
No & 62 & 22.4 \\
Yes & & \\
\hline Sources of finance & 216 & 78.0 \\
Parents & 13 & 4.6 \\
Other family members & 32 & 5.8 \\
Self & 16 & \\
Spouse & & \\
\hline
\end{tabular}

Table 3: Academic Characteristics of the Respondents

\begin{tabular}{|l|c|c|}
\hline Variable & Frequency & Percentage \\
\hline $\begin{array}{l}\text { Department } \\
\text { Medicine }\end{array}$ & 118 & 42.6 \\
\hline
\end{tabular}




\begin{tabular}{|l|c|c|}
\hline Nursing & 88 & 31.8 \\
Medical laboratory science & 71 & 25.6 \\
\hline Level & 42 & \\
300 & 72 & 15.2 \\
400 & 129 & 26.0 \\
500 & 34 & 46.5 \\
600 & 7 & 12.3 \\
\hline Rating of academic performance & 129 & 2.5 \\
Below average & 141 & 46.6 \\
Average & & 50.9 \\
Above average & 17 & 6.2 \\
\hline CGPA & 120 & 43.3 \\
$\geq 4.5$ & 22 & 7.9 \\
\hline $3.5-4.49$ & 172 & \\
$2.5-2.49$ & & \\
\hline
\end{tabular}

*sum less than total cohort because those not applicable were excluded

Table 4: Family Characteristics of the Respondents

\begin{tabular}{|c|c|c|}
\hline Variable & Frequency & Percentage \\
\hline \multicolumn{3}{|l|}{ Marital status of parent } \\
\hline Single parent & 13 & 4.7 \\
\hline Married & 216 & 78.0 \\
\hline Divorced/separated & 10 & 3.6 \\
\hline Widow/widower & 38 & 13.7 \\
\hline \multicolumn{3}{|l|}{ Type of family } \\
\hline Monogamous & 216 & 78.0 \\
\hline Polygamous & 61 & 22.0 \\
\hline \multicolumn{3}{|l|}{ Number of children(father) } \\
\hline$<5$ & 159 & 57.4 \\
\hline$\geq 5$ & 118 & 42.6 \\
\hline \multicolumn{3}{|l|}{ Number of children(mother) } \\
\hline$<5$ & 185 & 66.8 \\
\hline$\geq 5$ & 92 & 33.2 \\
\hline \multicolumn{3}{|l|}{ Position among father's children } \\
\hline First & 87 & 31.4 \\
\hline Between & 150 & 54.2 \\
\hline Last & 40 & 14.4 \\
\hline \multicolumn{3}{|l|}{ Position among mother's children } \\
\hline First & 100 & 36.1 \\
\hline Between & 130 & 46.9 \\
\hline Last & 47 & 17.0 \\
\hline \multicolumn{3}{|l|}{ Father's class of occupation } \\
\hline Low class & 71 & 25.6 \\
\hline High class & 206 & 74.4 \\
\hline \multicolumn{3}{|l|}{ Mother's class of occupation } \\
\hline Low class & 98 & 35.4 \\
\hline High class & 179 & 64.6 \\
\hline \multicolumn{3}{|l|}{ Father's level of education } \\
\hline Nil & 13 & 4.7 \\
\hline Primary & 14 & 5.1 \\
\hline Secondary & 34 & 12.2 \\
\hline Tertiary & 216 & 78.0 \\
\hline \multicolumn{3}{|l|}{ Mother's level of education } \\
\hline Nil & 11 & 4.0 \\
\hline Primary & 14 & 5.0 \\
\hline Secondary & 42 & 15.2 \\
\hline Tertiary & 210 & 75.8 \\
\hline
\end{tabular}


Falade, J., Eegunranti, B. A., Tobih, J. E., Ogundiran, A. C., Ibigbami, O., Akinsulore, A., Ogundiran, O. (2019). Prevalence, Pattern And Correlates Of Study Difficulty Among Students Of College Of Health Sciences Ladoke Akintola University Of Technology Osogbo. Advances in Social Sciences Research Journal, 6(9) 322-338.

Table 5: Study Difficulty among the Respondents

\begin{tabular}{|l|c|c|c|c|}
\hline $\begin{array}{l}\text { Subscales of } \\
\text { UCLSQ }\end{array}$ & $\begin{array}{c}\text { Mean } \\
\text { score( } \pm \text { SD) }\end{array}$ & $\begin{array}{c}\text { Low Scorer } \\
\mathbf{n}(\%)\end{array}$ & $\begin{array}{c}\text { Moderate Scorer } \\
\mathbf{n}(\%)\end{array}$ & $\begin{array}{c}\text { High Scorer } \\
\mathbf{n}(\%)\end{array}$ \\
\hline ANX & $6.6(3.6)$ & $36(13.0)$ & $199(71.8)$ & $42(15.2)$ \\
\hline OBS & $8.3(3.1)$ & $89(32.1)$ & $148(53.4)$ & $40(14.5)$ \\
\hline DEP & $5.2(2.7)$ & $83(30.0)$ & $148(53.4)$ & $46(16.6)$ \\
\hline DIS & $4.6(3.2)$ & $81(29.3)$ & $138(49.8)$ & $58(20.9)$ \\
\hline LMOT & $5.1(3.3)$ & $34(12.3)$ & $200(72.2)$ & $43(15.5)$ \\
\hline SOM & $4.4(3.5)$ & $42(15.2)$ & $196(70.7)$ & $39(14.1)$ \\
\hline WSAT * & $11.3(2.9)$ & $45(16.1)$ & $194(70.1)$ & $38(13.8)$ \\
\hline SYL & $9.8(3.1)$ & $33(11.9)$ & $204(73.6)$ & $40(14.5)$ \\
\hline
\end{tabular}

*Low scorers on this subscale are required as having study difficulty because low scorer indicate higher disturbance on the subscales.

Table 5 shows the classification of respondents into low, moderate and high scorers. On the Anxiety (ANX) subscale, 15.2\% were high scorers while $71.8 \%$ and $13.0 \%$ were moderate and low scorers respectively. Forty (14.5\%) respondents on the Obsessionality (OBS) subscale scored high while $53.4 \%$ and $32.1 \%$ were moderate and low scorers respectively. On the Depressive (DEP) subscale, half of the respondents were moderate scorers while 16.6\% were high scorers. Similarly, half of the respondents in the Disorganization scale were middle scorers while 20.9\% were high scorers. On the Low motivation (LMOT) subscale, 15.5\% were high scorers while $12.3 \%$ were low scorers. Two- third of the respondents on the Somatic (SOM) subscale were moderate scorers while $14.1 \%$ were high scorers. Similarly, two-third of the respondents on the Work Satisfaction (WSAT) subscale were moderate scorers while $13.4 \%$ were low scorers, $14.5 \%$ of respondents on the Sylibism (SYL) sub-scale had high scores.

The lowest proportion of high scorers (14.1\%) was recorded on the SOM while the highest (20.9\%) was recorded on the DIS subscale.

Overall, 144 (52.0\%) of the respondents had high score in one or low score on WSAT subscale of the subscales of UCLSQ. Thus, $52.0 \%$ of the respondents in this study were considered as having study difficulty.

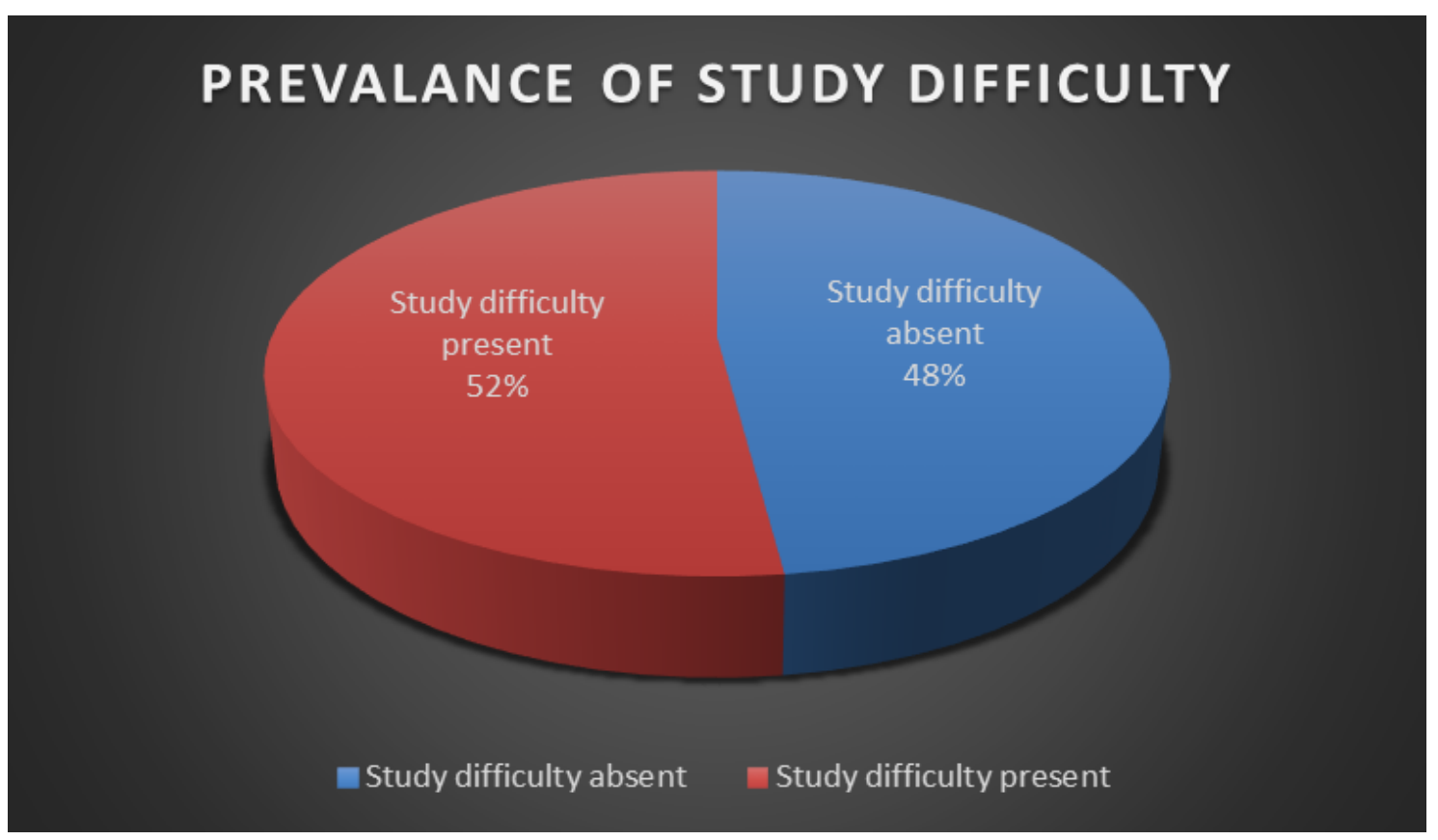

Fig 1: Association of Study Difficulty with the Socio-Demographic Characteristics of the Respondents 
Table 6: Association of Study Difficulty with Socio-Demographic Characteristics of the Respondents

\begin{tabular}{|c|c|c|c|c|c|}
\hline Variable & $\begin{array}{c}\text { Study difficulty } \\
\text { absent } \\
n(\%) \\
\end{array}$ & $\begin{array}{l}\text { Study } \\
\text { difficulty } \\
\text { present } \\
\mathrm{n}(\%)\end{array}$ & $X^{2}$ & $d f$ & pvalue \\
\hline \multicolumn{6}{|l|}{ Age in group } \\
\hline$<25$ & $27(36.5)$ & $47(63.5)$ & FET & 1 & 0.022 \\
\hline$\geq 25$ & $106(52.2)$ & $97(47.8)$ & & & \\
\hline \multicolumn{6}{|l|}{ Sex } \\
\hline Male & $67(57.8)$ & $49(42.2)$ & FET & 1 & 0.007 \\
\hline Female & $66(41.0)$ & $95(59.0)$ & & & \\
\hline \multicolumn{6}{|l|}{ Marital status } \\
\hline Single & 115(47.1) & $129(52.9)$ & FET & 1 & 0.426 \\
\hline Married & $18(54.5)$ & $15(45.5)$ & & & \\
\hline \multicolumn{6}{|l|}{ Ethnicity } \\
\hline Yoruba & $123(48.6)$ & $130(51.4)$ & 1.37 & 2 & 0.503 \\
\hline Ibo & $6(35.3)$ & $11(64.7)$ & & & \\
\hline Hausa & $4(57.1)$ & $3(42.9)$ & & & \\
\hline \multicolumn{6}{|l|}{ Religion } \\
\hline Christianity & $109(49.5)$ & $111(50.5)$ & 2.48 & 2 & 0.290 \\
\hline Islam & $24(43.6)$ & $31(56.4)$ & & & \\
\hline Traditional & $0(0.0)$ & $2(100.0)$ & & & \\
\hline \multicolumn{6}{|l|}{ Monthly allowance } \\
\hline$<20,000$ & $63(47.7)$ & $69(52.3)$ & 0.40 & 2 & 0.820 \\
\hline $20,000-39,999$ & $63(49.2)$ & $65(50.8)$ & & & \\
\hline$\geq 40,000$ & $7(41.2)$ & $10(58.8)$ & & & \\
\hline \multicolumn{6}{|c|}{ Satisfaction with allowance } \\
\hline No & $96(44.7)$ & $119(55.3)$ & FET & 1 & 0.026 \\
\hline Yes & $37(59.7)$ & $25(40.3)$ & & & \\
\hline \multicolumn{6}{|l|}{ Source of finance } \\
\hline Parents & $105(48.6)$ & $111(51.4)$ & 0.30 & 3 & 0.959 \\
\hline Other family members & $6(46.2)$ & $7(53.8)$ & & & \\
\hline Self & $14(43.8)$ & $18(56.3)$ & & & \\
\hline Spouse & $8(50.0)$ & $8(50.0)$ & & & \\
\hline \multicolumn{6}{|c|}{ Psychoactive substance use } \\
\hline No drug use & $110(48.5)$ & $117(51.5)$ & 0.10 & 1 & 0.438 \\
\hline Drug use & $23(46.0)$ & $27(54.0)$ & & & \\
\hline
\end{tabular}

FET-Fisher's Exact Test

Table 6 shows the association between study difficulty and the socio-demographic characteristics of the respondents based on the comparison of 133 subjects without study difficulty and the 144 subjects with study difficulty

Respondents less than 25 years (63.5\%) had more study difficulty than respondents who were greater or equal to 25 years. The difference was statistically significant. $(p=0.022)$. More female respondents (59.0\%) had study difficulty than the males (42.2\%). This difference is statistically significant $(p=0.007)$. Also, significantly more undergraduates who were not satisfied with their monthly allowance (55.3\%) had study difficulty than those who were satisfied $(p=0.046)$.

Significantly, higher proportions of respondents who practices traditional religion (100\%), those that earn \#40,000 and above (58.8\%) and those that were self-sponsored (56.2\%) were observed with study difficulty. Also, non-psychoactive substance user (57.5\%) had more study difficulty than psychoactive substance users. However, all these differences were not significant $(\mathrm{p}>0.05)$. 
Falade, J., Eegunranti, B. A., Tobih, J. E., Ogundiran, A. C., Ibigbami, O., Akinsulore, A., Ogundiran, O. (2019). Prevalence, Pattern And Correlates Of Study Difficulty Among Students Of College Of Health Sciences Ladoke Akintola University Of Technology Osogbo. Advances in Social Sciences Research Journal, 6(9) 322-338.

Table 7: Association of Study Difficulty with Academic Characteristics of the Respondents

\begin{tabular}{|c|c|c|c|c|c|}
\hline Variable & $\begin{array}{c}\text { No study } \\
\text { difficulty } \\
\text { n(\%) }\end{array}$ & $\begin{array}{c}\text { Study } \\
\text { difficulty } \\
\text { present } \\
\text { n(\%) }\end{array}$ & $X^{2}$ & $d f$ & pvalue \\
\hline \multicolumn{6}{|l|}{ Department } \\
\hline Medicine & $59(50.0)$ & $59(50.0)$ & 8.50 & 2 & 0.014 \\
\hline Nursing & $32(36.4)$ & $56(63.6)$ & & & \\
\hline Medical laboratory science & $42(59.2)$ & $29(40.8)$ & & & \\
\hline \multicolumn{6}{|l|}{ Level } \\
\hline 300 & $18(42.9)$ & $24(57.1)$ & 6.79 & 3 & 0.079 \\
\hline 400 & $27(37.5)$ & $45(62.5)$ & & & \\
\hline 500 & $72(55.8)$ & $57(44.2)$ & & & \\
\hline 600 & $16(47.1)$ & $18(52.9)$ & & & \\
\hline \multicolumn{6}{|l|}{ Academic performance } \\
\hline Below average & $4(57.1)$ & $3(42.9)$ & 1.02 & 2 & 0.599 \\
\hline Average & $58(45.0)$ & $71(55.0)$ & & & \\
\hline Above average & $71(50.4)$ & $70(49.6)$ & & & \\
\hline \multicolumn{6}{|l|}{ CGPA* $^{*}$} \\
\hline $1^{\text {st }}$ class & $11(64.7)$ & $6(35.3)$ & 2.54 & 2 & 0.281 \\
\hline $2^{\text {nd }}$ class upper & $53(44.2)$ & $67(55.8)$ & & & \\
\hline $2^{\text {nd }}$ class lower & $10(45.5)$ & $12(54.5)$ & & & \\
\hline
\end{tabular}

*sum less than total cohort because those not applicable were exclude

Table 7 shows the association of study difficulty with academic characteristics of the respondents. More Nursing Science Students (63.6\%) had study difficulty than medical students (50.0\%) who in turn have more study difficulty compared with Medical Laboratory Science Students (39.4\%). This observation is statistically significant $(\chi 2=8.50, \mathrm{p}$ value $=$ $0.014)$. Respondents in 400 level (61.1\%), average students (55.0\%) and those that had second class upper $(55.8 \%)$ had study difficulty among their respective groups and however the differences are not statistically significant. 
Table 8: Association of Study Difficulty with Family Characteristics of the Respondents

\begin{tabular}{|c|c|c|c|c|c|}
\hline Variable & $\begin{array}{l}\text { Study difficulty } \\
\text { absent } \\
\mathrm{n}(\%)\end{array}$ & $\begin{array}{l}\text { Study difficulty } \\
\text { present } \\
n(\%)\end{array}$ & $X^{2}$ & $d f$ & Pvalue \\
\hline $\begin{array}{l}\text { Marital status of parent } \\
\text { Single parent } \\
\text { Married } \\
\text { Divorced } \\
\text { Separated } \\
\end{array}$ & $\begin{array}{c}9(69.2) \\
99(45.8) \\
8(80.0) \\
17(44.7)\end{array}$ & $\begin{array}{c}4(30.8) \\
117(54.2) \\
2(20.0) \\
21(55.3) \\
\end{array}$ & 7.01 & 3 & 0.071 \\
\hline $\begin{array}{l}\text { Type of family } \\
\text { Monogamous } \\
\text { Polygamous }\end{array}$ & $\begin{array}{c}104(48.1) \\
29(47.5)\end{array}$ & $\begin{array}{l}112(51.9) \\
32(52.5)\end{array}$ & FET & 1 & 0.525 \\
\hline $\begin{array}{l}\text { Number of children(father) } \\
<5 \\
\geq 5\end{array}$ & $\begin{array}{l}70(44.0) \\
63(53.4) \\
\end{array}$ & $\begin{array}{l}89(56.0) \\
55(46.6)\end{array}$ & FET & 1 & 0.078 \\
\hline $\begin{array}{l}\text { Number of children(mother) } \\
<5 \\
\geq 5\end{array}$ & $\begin{array}{l}83(44.9) \\
50(54.3)\end{array}$ & $\begin{array}{c}102(55.1) \\
42(45.7)\end{array}$ & FET & 1 & 0.087 \\
\hline $\begin{array}{l}\text { Position among father's } \\
\text { children } \\
\text { First child } \\
\text { Middle child } \\
\text { Last child } \\
\end{array}$ & $\begin{array}{l}39(44.8) \\
72(48.0) \\
22(55.0)\end{array}$ & $\begin{array}{l}48(55.2) \\
78(52.0) \\
18(45.0)\end{array}$ & 1.14 & 2 & 0.567 \\
\hline $\begin{array}{l}\text { Position among mother's } \\
\text { children } \\
\text { First child } \\
\text { Middle child } \\
\text { Last child } \\
\end{array}$ & $\begin{array}{l}42(42.0) \\
66(50.8) \\
25(53.2) \\
\end{array}$ & $\begin{array}{l}58(58.0) \\
64(49.2) \\
22(46.8) \\
\end{array}$ & 2.35 & 2 & 0.309 \\
\hline $\begin{array}{l}\text { Father's class of occupation } \\
\text { Low class } \\
\text { High class }\end{array}$ & $\begin{array}{c}31(43.7) \\
102(49.5)\end{array}$ & $\begin{array}{c}40(56.3) \\
104(50.5)\end{array}$ & FET & 1 & 0.238 \\
\hline $\begin{array}{l}\text { Mother's class of occupation } \\
\text { Low class } \\
\text { High class }\end{array}$ & $\begin{array}{l}45(45.9) \\
88(49.2)\end{array}$ & $\begin{array}{l}53(54.1) \\
91(50.8)\end{array}$ & FET & 1 & 0.348 \\
\hline $\begin{array}{l}\text { Father's level of education } \\
\text { Nil } \\
\text { Primary } \\
\text { Secondary } \\
\text { Tertiary }\end{array}$ & $\begin{array}{c}7(53.8) \\
7(50.0) \\
14(41.2) \\
105(48.6)\end{array}$ & $\begin{array}{c}6(46.2) \\
7(50.0) \\
20(58.8) \\
111(51.4)\end{array}$ & 0.867 & 3 & 0.833 \\
\hline $\begin{array}{l}\text { Mother's level of education } \\
\text { Nil } \\
\text { Primary } \\
\text { Secondary } \\
\text { Tertiary }\end{array}$ & $\begin{array}{c}5(45.5) \\
9(64.3) \\
13(31.0) \\
106(50.5) \\
\end{array}$ & $\begin{array}{c}6(54.5) \\
5(35.7) \\
29(69.0) \\
104(49.5) \\
\end{array}$ & 6.92 & 3 & 0.074 \\
\hline
\end{tabular}

FET-Fisher's Exact Test

Table 8 shows the association of study difficulty with family characteristics of the respondents. Students from separated home had the highest proportion (55.3\%) with study difficulty among the group. However, this difference is not significant. In the same vein, respondents from monogamous settings, those with father's children above 4, mother's children less than 5 , first child of their parents, parents with low class of occupation, fathers with tertiary or mothers with secondary education had high proportion with study difficulty among their respective groups but the differences are not statistically significant. 
Falade, J., Eegunranti, B. A., Tobih, J. E., Ogundiran, A. C., Ibigbami, O., Akinsulore, A., Ogundiran, O. (2019). Prevalence, Pattern And Correlates Of Study Difficulty Among Students Of College Of Health Sciences Ladoke Akintola University Of Technology Osogbo. Advances in Social Sciences Research Journal, 6(9) 322-338.

Table 9: Comparison of Mean Scores of the Brief Cope between Respondents with Study Difficulty and those without Study Difficulty

\begin{tabular}{|c|c|c|c|c|c|}
\hline $\begin{array}{l}\text { COPING } \\
\text { CATEGORY }\end{array}$ & $\begin{array}{c}\text { Study difficulty } \\
\text { absent } \\
\text { Mean( } \pm \text { SD })\end{array}$ & $\begin{array}{c}\text { Study difficulty } \\
\text { present } \\
\text { Mean }( \pm S D)\end{array}$ & $T$ & $d f$ & pvalue \\
\hline Adaptive coping & $42.52(10.07)$ & 39.5(8.92) & 2.63 & 275 & 0.009 \\
\hline $\begin{array}{l}\text { Maladaptive } \\
\text { coping }\end{array}$ & $21.66(4.73)$ & $22.91(5.55)$ & -2.01 & 275 & 0.046 \\
\hline
\end{tabular}

\section{Comparison of Mean Coping Scores of Respondents with Study Difficulty and those without Study Difficulty}

Table 9 shows the comparison of mean scores on the coping strategies of respondents without study difficulty and respondents with study difficulty. Respondents with study difficulty had higher maladaptive scores than respondents without study difficulty. The difference is statistically significant $(\mathrm{p}=0.046)$. Also, respondents without study difficulty had higher adaptive scores than respondents with study difficulty. The difference is also statistically significant $(\mathrm{p}=0.009)$.

Table 10: Association between study difficulty and psychiatric morbidity

\begin{tabular}{|c|c|c|c|c|c|}
\hline Variable & $\begin{array}{l}\text { Study difficulty } \\
\text { absent } \\
\text { n(\%) }\end{array}$ & $\begin{array}{l}\text { Study difficulty } \\
\text { present } \\
n(\%)\end{array}$ & $X^{2}$ & $d f$ & pvalue \\
\hline $\begin{array}{l}\text { Psychiatric } \\
\text { morbidity absent }\end{array}$ & $120(58.0)$ & $87(42.0)$ & 32.53 & 1 & $<0.001$ \\
\hline $\begin{array}{l}\text { Psychiatric } \\
\text { Morbidity present }\end{array}$ & $13(18.6)$ & $57(81.4)$ & & & \\
\hline
\end{tabular}

Table 10 shows the association between study difficulty and psychiatric morbidity among the respondents based on the comparison of 133 subjects without study difficulty and the 144 subjects with study difficulty. Greater proportion $(81.4 \%)$ of respondents with psychiatric morbidity had study difficulty compared to $42.0 \%$ of those without psychiatric morbidly. This observation is statistically significant $(X 2=32.53$, pvalue $<0.001)$. 
Table 11: Association between Study Difficulty and other Variables using Logistic Regression.

\begin{tabular}{|c|c|c|c|c|c|}
\hline \multirow[t]{2}{*}{ Variable } & \multirow[t]{2}{*}{ B } & \multirow[t]{2}{*}{ Odd ratio } & \multirow[t]{2}{*}{$P$ value } & \multicolumn{2}{|c|}{ 95\% CL for EXP(B) } \\
\hline & & & & Lower & Higher \\
\hline $\begin{array}{l}\text { Gender } \\
\text { male(ref) } \\
\text { female }\end{array}$ & $\begin{array}{c}1 \\
0.406\end{array}$ & $\begin{array}{c}1 \\
1.229\end{array}$ & 0.533 & 0.643 & 2.246 \\
\hline $\begin{array}{c}\text { Age group } \\
\geq 25 \\
<25\end{array}$ & $\begin{array}{c}1 \\
0.210\end{array}$ & $\begin{array}{c}1 \\
1.24\end{array}$ & 0.530 & 0.640 & 2.382 \\
\hline $\begin{array}{l}\text { Department } \\
\text { MLS(ref } \\
\text { medicine } \\
\text { Nursing }\end{array}$ & $\begin{array}{c}1 \\
0.628 \\
0.499\end{array}$ & $\begin{array}{c}1 \\
1.873 \\
1.647\end{array}$ & $\begin{array}{l}0.084 \\
0.231\end{array}$ & $\begin{array}{l}0.919 \\
0.725\end{array}$ & $\begin{array}{l}3.816 \\
3.743\end{array}$ \\
\hline $\begin{array}{l}\text { Satisfy with } \\
\text { monthly } \\
\text { allowance } \\
\text { Satisfied(ref) } \\
\text { Not satisfied }\end{array}$ & $\begin{array}{c}1 \\
0.206\end{array}$ & $\begin{array}{c}1 \\
0.533\end{array}$ & 0.533 & 0.643 & 2.346 \\
\hline $\begin{array}{l}\text { Maladaptive } \\
\text { coping } \\
\text { mechanism }\end{array}$ & 0.47 & 1.048 & 0.134 & 0.986 & 1.115 \\
\hline $\begin{array}{l}\text { Adaptive coping } \\
\text { mechanism }\end{array}$ & -0.47 & 0.954 & 0.005 & 0.924 & 0.986 \\
\hline $\begin{array}{l}\text { GHQ } \\
\text { Negative(ref) } \\
\text { Positive }\end{array}$ & $\begin{array}{c}1 \\
1.774\end{array}$ & $\begin{array}{c}1 \\
5.896\end{array}$ & $<0.001$ & 2.886 & 12.048 \\
\hline
\end{tabular}

Table 11 shows the results of logistic regression analysis with 95\% confidence interval using stepwise method to explore the factors independently associated with study difficulty. The socio-demographic and clinical variables were entered as independent variables and study difficulty was entered as dependent variable. The result revealed that the risk of Study difficulty was 5.8fold increase among those that were GHQ positive compared with those with GHQ negative $(B=1.774, \mathrm{P}<0.001)$.In addition, the risk of study difficulty was 0.92 fold decrease along each unit increase among in the mean value among respondents using adaptive coping strategies $(B=-0.047, P=0.005)$.

Gender, age group, satisfaction with monthly allowance and maladaptive coping strategies were not significant

\section{DISCUSSION}

The proportion of high scorers of the respondents on each subscale of UCLSQ ranged from $14.1 \%$ to $20.9 \%$, this pattern is similar to that reported by Ejikunle 2015 who found a range between $11.6 \%$ and $20.0 \%$ and Fatoye et al 1998 who reported a range between $18.1 \%$ and $23.1 \%$ among Nigerian students $[3,13]$. These studies were done in the same Geo-political zone while a slightly lower range of $4.5 \%$ and $15.3 \%$ was reported by Osasona et al, 2011 in the South-southern part of Nigerian [7]. This relative stability of the pattern has implication for remedial strategies, as any such would be effective from region to region in the country.

The prevalence of study difficulty among the respondents was $52.0 \%$ which is comparable to $53.8 \%$ reported by Uchendu et al, 2014 in Nigeria in Nigeria. It is noteworthy that the study was conducted among students in six (6) Faculties who were in their third and fourth year. The researchers divided their respondents into two groups namely; positive and negative by using the median on each of the UCLSQ subscales as the cut- off point [6]. 
Falade, J., Eegunranti, B. A., Tobih, J. E., Ogundiran, A. C., Ibigbami, O., Akinsulore, A., Ogundiran, O. (2019). Prevalence, Pattern And Correlates Of Study Difficulty Among Students Of College Of Health Sciences Ladoke Akintola University Of Technology Osogbo. Advances in Social Sciences Research Journal, 6(9) 322-338.

There are paucity of studies from other parts of the world on study difficulty among university for comparison. The relationship between the UCLSQ subscales showed noteworthy positive relationship with each other. This may suggest a significant degree of similarity among the items/subscales of the instrument. The division into subscales may therefore be for operational suitability only when analyzing study difficulty.

The study revealed that age 25 and above, being a female student, belonging to nursing department, non- satisfaction with monthly allowance, lesser use of adaptive coping, higher use of mal-adaptive coping strategies and psychiatric morbidity were significant correlates of study difficulty. However, psychiatric morbidity and using less of adaptive coping strategies were the main predictors of study difficulty.

Psychiatric morbidity has a significant and positive correlation with the following aspects of study difficulty namely: Anxiety, Depression, Disorganized, Low motivation, Somatic symptoms but a negative correlation with Work satisfaction. The positive correlation coefficients recorded are understandable because the two scales somewhat measure similar variable mental health status. One of the possible explanations is that the UCLSQ measures the emotional and motivational aspects of study difficulty. Therefore, mental health screening and management would be expected to reduce study difficulty. Therefore, such prompt recognition of mental health challenges among the students is important. Thus, study suggests that student mental health services would be needed in higher educational institutions.

This study revealed that lesser use of adaptive coping strategy is a predictor of Study difficulty. Studying in the College of Health Sciences requires hard work and the use of adaptive coping strategies. Adaptive coping strategies can help undergraduate students to enhance their academic performance, improve class attendance, increase participation, encourage persistence even when faced with setbacks or failure in general, and make them stronger and resilient to cope with learning. Adaptive coping strategies would help undergraduate students to perform well in their academics and improve their physical, emotional, spiritual, and psychological well-being. Using adaptive coping strategies is a good indicator of student's mental health stability, which in turn, promotes effective studying. However, maladaptive coping strategies have a negative impact on mental health and studying. From these observations, these two variables mental health status and adaptive coping strategies are pivotal to the prevention of study difficulty and are therefore important ingredients of any envisaged remedial program, such programs appear urgent in view of the high rate of study difficulty uncovered in this study.

This study revealed that there was a significant association between study difficulty and psychiatric morbidity. Psychiatric morbidity was associated with six subscales of study difficulty namely Anxiety (ANX), Obsessionality (OBS), Depression (DEP), Disorganizeddistractible (DIS) Low-motivation (LMOT). Greater percentage (81.4\%) of those with psychiatric morbidity had study difficulty. This is higher than 13.1 to $45.9 \%$ across all the subscales of UCLSQ reported by Osasona et al 2011 [7]. The significant association between study difficulty and psychiatric morbidity found in our study corroborated with the result from the study by Fatoye 1998 who found a pattern, which indicated that study difficulty was associated with psychopathology and commoner among students who were relatively high scorers on neuroticism and psychoticism [3].

Hanforth et al.,1978 reported that one third of the students with study difficulty at Queen's University Health Service complained of both anxiety and depression. Although these findings 
have shown that students with psychiatric morbidity are liable to have study difficulty of some type, the relationship between psychiatric morbidity and study difficultly may be far from simple because study difficulty may predispose to psychiatric morbidity as well as psychiatric morbidity predisposing to study difficulty [2].

\section{CONCLUSION}

Is study difficulty a direct result of psychiatric morbidity or did psychiatric morbidity arise as a product of frustrations occasioned by study difficulty? An understanding of the underlying mechanism of this association is important and it is hoped that some future studies will address this through longitudinal approach.

The study revealed that there is relationship between coping strategies, psychiatric morbidity and study difficulty among students of College of Health Science, Osogbo. The use of maladaptive coping strategies was associated with psychiatric morbidity while lesser use of adaptive coping strategies and psychiatric morbidity were associated study difficulty. If a student uses adaptive coping strategies there is lesser tendency for the student to have psychiatric morbidly and difficulty in studying ultimately. Studying requires sound mental health and effective coping strategies; therefore, students with psychiatric morbidity may have difficulty in studying and use more of maladaptive coping strategies.

\section{RECOMMENDATIONS}

- There is a need to teach adaptive coping strategies among undergraduates because of the positive relationship between maladaptive coping strategies and study difficulty.

- Educators and policy makers should reduce stress associated with academic syllabus so that students can bound well with their study.

- We advocate for prompt and regular mental health assessment among undergraduate students. These may help to reduce psychiatric morbidity and study difficulty among this population.

- Finally, we recommend practical teaching of adaptive coping strategy in the citadels of learning in Nigeria particular in the tertiary level / medical and paramedical professions.

\section{References}

Fatoye, F. O. and Morakinyo, 0. Study difficulty and brain fag syndrome in southwestern Nigeria Journal of Psychology in Africa, 2003; 13(1), 70-80.

Handforth, James R. Study difficulty: psychiatric and psychological aspects. Canadian Psychiatric Association Journal, 1978; 23(8), 549-556.

Fatoye, F. O. Drug Use, Study Difficulty and Psychopathology among secondary school students in Osun State, Study Submitted to National Postgraduate College of Psychiatry; 1998.

Crown, Sidney, Lucas, CJ, and Supramaniam, S. The delineation and measurement of study difficulty in university students. The British Journal of Psychiatry, 1973; 123(575), 381-393.

Blain, G. B., and Mc Arthur, C. C. Emotional Problems of the Student. 1st edition New York. Double day and CO; 1966; 83-84.

Uchendu, I. U., Chikezie, E. U., Morakinyo. O. Brain Fag Syndrome among Nigerian University Student in Abuja. Journal of Psychiatry and Brain Function, 2014; 1, 1-6

Osasona, SO, Morakinyo, 0 and Akhibe, KO. Study Difficulty Amongst Undergraduates in a Nigerian University: Pattern and Relationship with Psychiatric Morbidity and Academic Performance. Nigerian Journal of Psychiatry, 2001; 9(3), 46-53.

Malleson, Nicolas Borrell. A Handbook of British student health services: Pitman Medical, 1965.

Ryle, A. Student casualties. 1st Edition. London. Penguine Press. 1969; 81-83 
Falade, J., Eegunranti, B. A., Tobih, J. E., Ogundiran, A. C., Ibigbami, O., Akinsulore, A., Ogundiran, O. (2019). Prevalence, Pattern And Correlates Of Study Difficulty Among Students Of College Of Health Sciences Ladoke Akintola University Of Technology Osogbo. Advances in Social Sciences Research Journal, 6(9) 322-338.

Morakinyo, O. Student Mental health in Africa; Present status and future prospect. 15thAnual Lecture of West African College of Physician Accara Ghana; 1990.

Makanjuola, Victor A, Onyeama, Mbadiwe, Nuhu, Folorunsho T, Kola, Lola and Gureje, Oye. Validation of short screening tools for common mental disorders in Nigerian general practices. General hospital psychiatry, 2014; 36(3), 325-329.

Lucas, C. J., Ucas, S., Crown, P. and Supramaniam, S. Further observation on study difficulty in university students including syllabus-boundness. British. Journal of Psychiatry, 1976. 129(6), 598 -603.

Ejikunle, R. T. Psychaitric morbidity, personality profile and study difficulty among undergraduate. A master's thesis submitted to the post graduate college at Obafemi Awolowo University, Ile Ife, 2015. 